\title{
Error Analysis on Descriptive and Narrative Writing of The Fifth Grade Student's Indonesian Language Lesson
}

\section{Aris Wuryantoro; Dwi Rohman Soleh; Rika Prasetya Cahyaningtyas}

Universitas PGRI Madiun.

aris.wuryantoro@unipma.ac.id

\section{Article History}

accepted 24/09/2019

approved 01/10/2019

published 01/12/2019

\begin{abstract}
This research is aimed to describe the error and its causes made by fifth grade students of SDN Bangunrejo Kidul 1 Kedunggalar, Ngawi on descriptive and narratives writing in Indonesian language lessons. The research method was descriptive qualitative to results of descriptive and narratives writing of fifth grade students of SDN Bangunrejo Kidul 1, Kedunggalar, Ngawi on Indonesian language lessons. Data obtained by using observation, interview and documentation technique. Data analyzed through reduction, presentation, and draw conclusions. Research reveals that fifth grade students still have error on descriptive and narrative writing in capital letter, punctuation, and prepositions or passive verb di-. Class V students' error on descriptive and narrative writing are caused by the lack of language rules, accuracy and haste of students in descriptive and narrative writing of Indonesian language.
\end{abstract}

Keywords: error analysis, writing, descriptive, narrative

\section{Abstrak}

Penelitian ini ditujukan untuk mendeskripsikan kesalahan dan penyebabnya dalam menulis deskripsi dan narasi pada pelajaran bahasa Indonesia yang dilakukan oleh siswa kelas V SDN Bangunrejo Kidul 1, Kedunggalar, Ngawi. Metode penelitian ini menggunakan kualitatif deskriptif pada subjek penelitian yakni hasil menulis deskripsi dan narasi pada pelajaran bahasa Indonesia. Data dikumpulkan melalui teknik pengamatan, wawancara dan dokumentasi. Data dianalisis dengan cara reduksi, penyajian, dan menarik simpulan data. Penelitian membuktikan bahwa siswa kelas $\mathrm{V}$ masih melakukan kesalahan dalam menulis deskripsi dan narasi pada penggunaan huruf kapital, tanda baca titik, dan kata depan atau verba di-. Kesalahan siswa Kelas $\mathrm{V}$ dalam menulis deskripsi dan narasi disebabkan oleh kurang menguasai kaidah bahasa, kurang teliti dan ketergesa-gesaan siswa pada pelajaran menulis deskripsi dan narasi dalam bahasa Indonesia.

Kata kunci: analisis kesalahan, menulis, deskripsi, narasi

Social, Humanities, and Education Studies (SHEs): Conference Series https://jurnal.uns.ac.id/shes 


\section{PENDAHULUAN}

Penguasaan bahasa Indonesia dalam berkomunikasi dikembangkan melalui empat bidang bahasa, yaitu menulis, menyimak, berbicara, dan membaca. Menyitir dari pendapat Slamet (2009: 95) bahwa menulis sangat menentukan berhasiltidaknya siswa dalam kegiatan belajara mengajar karena siswa atau pelajar dalam mengikuti kegiatan belajar mengajar di sekolah banyak ditentukannya oleh kegiatan menulis. Karena itu, menulis merupakan hal terpenting dari sebuah pembelajaran. Menulis sangat berhubungan erat dengan pembelajaran lainnya. Keterampilan menulis merupakan kemampuan yang paling sulit dari ke empat keterampilan berbahasa yang lainnya. Di sisi lain, Dalman (2014: 3-4) mengungkapkan bahwa ada dua kegiatan yang dilakukan dalam menulis, yaitu proses kreatif menuangkan gagasan dalam bentuk bahasa tulis serta kegiatan merangkai huruf menjadi kata atau kalimat untuk disampaikan kepada pembaca. Dari pernyataan di atas dapat dikatakan bahwa untuk ketrampilan menulis adalah keterampilan bahasa yang sangat diperlukan atau penting bagi siswa untuk menunjang keberhasilannya dalam proses belajar. Bahkan dapat dikatakan pula bahwa untuk menjadi seorang siswa yang mumpuni hendaknya siswa tersebut dapat menuangkan gagasannya dengan baik dalam bentuk tulisan yang sekreatif mungkin agar gagasan yang dimilikinya dapat tersampaikan dengan mudah dipahami dan menarik bagi pembacanya.

Deskripsi, menurut Suparno, adalah bentuk wacana yang menggambarkan ataupun melukiskan sesuatu yang berasal dari perasaan, pengamatan, dan pengalaman penulisnya. Adapun tujuannya adalah untuk menciptakan imajinasi pembaca seakan-akan mengalami, merasakan, dan melihat sendiri apa yang dialami penulisnya (2011: 111). Di sisi lain, narasi adalah bentuk wacana yang berusaha menjelaskan suatu peristiwa atau kejadian agar tampak seakan-akan peristiwa tersebut dialami atau dilihat sendiri oleh pembaca. Oleh karena itu, tindakan atau perbuatan merupakan unsur penting dalam sebuah narasi (Keraf dalam Zen, 2009: 15).

Markhamah dan Sabardila (2010) menjelaskan perbedaan antara kekeliruan (mistake) dan kesalahan (error) dalam berbahasa. Kekeliruan berbahasa merupakan penyimpangan non sistematis yang berada pada area perilaku atau performansi dalam berbahasa. Sedangkan kesalahan berbahasa merupakan bentuk dari penyimpangan yang konsisten, sistematis, serta menggambarkan kemampuan peserta didik pada tahap tertentu. Namun demikian, kesalahan dalam berbahasa yang dilakukan oleh peserta didik harus dikurangi semaksimal mungkin. Di sisi lain, Setyawati (2010) menyatakan bahwa kesalahan berbahasa Indonesia adalah segala bentuk penyimpangan atau pelanggaran dalam menggunakan bahasa baik tulis maupun lisan yang berada di luar atau menyimpang dari dari aturan atau kaidah kebahasaan dalam bahasa Indonesia. Sementara itu, Samsuri (dalam Sholikah, Suyitno, dan Martutik, 2013) menyatakan bahwa analisis kesalahan bahasa merupakan kegiatan studi pada semua aspek penyimpangan dalam berbahasa itu sendiri. Analisis kesalahan berbahasa ini sangat diperlukan untuk mengetahui fungsi bahasa baik secara lisan, tulis, maupun susunannya. Tujuan dari analisis kesalahan berbahasa adalah sebagai umpan balik untuk menyusun materi pembelajaran bahasa. Guru, dengan teori kesalahan bahasa, dapat menjelaskan kesalahan yang dilakukan oleh peserta didik dengan lebih berhasil, memuaskan, langsung, serta menghemat waktu.

Kesalahan menulis cukup menarik untuk diteliti guna meningkatkan kemampuan peserta didik dalam pelajaran bahasa khususnya pada pembelajaran menulis. Penelitian tentang analisis kesalahan antara lain telah dilakukan oleh Abdul Karim, dkk (2018); Ayudia, Edi Suryanto, dan Budhi Waluyo (2016); Rizki Ananda, Sofyan A Gani, dan Gani Rosnani Sahardi (2014); E. N. Sholikah, I. Suyitno, dan Martutik (2013); Ayuningsih. F.D (2012); dan Nur Endah Ariningsih, Sumarwati, dan Kundharu Saddhono (2012). Dalam penelitiannya, Abdul Karim, dkk (2018) mengungkap bahwa 
kesalahan terbesar dalam berbahasa tulis terletak pada tata bahasa, kesalahan informasi, kesalahan susunan kata dalam kalimat, dan generalisasi yang berlebihan. Namun demikian, penelitian ini juga menemukan pilihan yang kuat bagi pembelajar EFL untuk memperbaiki kesalahannya melalui bimbingan gurunya. Sedangkan penelitian Ayudia, Edi Suryanto, dan Budhi Waluyo (2016) menunjukkan bahwa: (1) kesalahan berbahasa yang dilakukan oleh siswa mencakup ejaan, diksi, penyusunan kalimat, dan paragraf; (2) kesalahan berbahasa yang dilakukan siswa disebabkan oleh empat faktor, yaitu siswa kurang menguasai kaidah bahasa, siswa tidak teliti dalam menulis, siswa kurang termotivasi menulis, dan siswa kurang menguasai banyak kosakata; dan (3) upaya untuk mengurangi kesalahan berbahasa yang dilakukan oleh siswa antara lain pembelajaran menulis melalui pendekatan proses, peningkatan penguasaan kaidah bahasa siswa dengan cara banyak membaca, dan peningkatan latihan dalam menulis.

Sementara, Rizki Ananda, Sofyan A Gani, dan Gani Rosnani Sahardi (2014) menemukan lima jenis kesalahan dalam penggalan kalimat (fragmented sentence), yaitu tidak adanya subjek, tidak ada kata verba, tidak ada subjek dan kata verba, tidak ada kata verba dalam dependent clause, dan tidak ada independent clause. Di sisi lain, E. N. Sholikah, I. Suyitno, dan Martutik (2013) dalam penelitiannya menemukan tiga kelompok kesalahan dalam berbahasa yang dilakukan oleh siswa, yaitu: (1) penggunaan ejaan dan tanda baca yang mencakup huruf kapital, preposisi, partikel, kata turunan, kata ganti, kata asing, angka dan lambang bilangan, singkatan, akronim, tanda titik, tanda koma, tanda kutip, tanda pisah, tanda hubung, tanda seru, tanda tanya, tanda titik dua, dan tanda titik koma; (2) penggunaan pilihan kata meliputi dua aspek, yaitu gramatikal dan leksikal; dan (3) penggunaan kalimat yang tidak lengkap, tidak tepat, tidak logis, tidak hemat, dan tidak jelas atau taksa. Sementara itu, Sementara Ayuningsih. F.D. (2012) dalam penelitiannya menunjukkan bahwa bentuk kesalahan berbahasa yang dilakukan oleh siswa Kelas X A SMK Batik 2 Surakarta meliputi bidang fonologi, kesalahan bidang morfologi, dan kesalahan bidang sintaksis

Sedangkan Nur Endah Ariningsih, Sumarwati, Kundharu Saddhono (2012) dalam penelitiannya menyimpulkan bahwa (1) ada empat kesalahan berbahasa yang dilakukan oleh siswa dalam menulis karangan yaitu kesalahan pada ejaan, pemilihan diksi, penyusunan kalimat, dan pembuatan paragraf; (2) penyebab kesalahan bahasa yang sering dilakukan oleh siswa dalam menulis karangan eksposisi antara lain kurangnya penguasaan bahasa siswa, siswa kurang latihan menulis karangan, guru kurang memberi contoh menulis karangan, kurangnya waktu yang tersedia dalam pelajaran menulis, serta adanya pengaruh bahasa asing; serta (3) upaya untuk mengurangi kesalahan berbahasa yang dilakukan oleh siswa dalam menulis karangan eksposisi siswa antara lain dengan cara meningkatkan penguasaan kaidah bahasa siswa, melaksanakan pembelajaran menulis melalui pendekatan proses, memperbanyak latihan menulis karangan, dan menerapkan teknik koreksi bahasa yang tepat.

Beberapa perbedaan antara penelitian ini dengan penelitian sebelumnya, atara lain objek penelitian, jenis kesalahan, serta penyebab kesalahan. Objek penelitian ini adalah siswa kelas V Sekolah Dasar. Objek penelitian sebelumnya yang dilakukan oleh Sholihah, Suyitno, dan Martutik (2013) serta penelitian yang dilakukan oleh Ayudia, Suryanto, dan Waluyo (2016) objek penelitian yang digunakan adalah siswa Sekolah Menengah Pertama atau sederajat. Sedangkan objek penelitian yang digunakan oleh Ayuningsih (2012) dan Ariningsih, Sumarwati, dan Saddhono (2012) adalah siswa Sekolah Menengah Atas. Sedangkan subjek penelitian yang dilakukan oleh para peneliti di atas adalah kesalahan dalam pelajaran bahasa Indonesia, sedangkan subjek penelitian yang dilakukan oleh Rizki Ananda, S.A. Gani, dan R. Sahardin (2014) dan Abdul Karim, dkk (2018) adalah kesalahan dalam pelajaran bahasa Inggris sebagai bahasa asing (EFL). Hal ini tentunya akan sangat menentukan 
perbedaan pada objek penelitian terutama dalam hal pengetahuan atau penguasaan kaidah bahasa.Selain itu, kesalahan-kesalahan dalam menulis yang dilakukan oleh siswa Kelas V Sekolah Dasar sedikit berbeda dengan siswa di tingkat atasnya. Jenis kesalahan yang ditemukan dalam penelitian ini sekitar penggunaan huruf kapital, penggunaan tanda baca, dan penggunaan kata di-. Sedangkan penelitian sebelumnya mencakup kesalahan pemilihan ejaan, diksi, kalimat, dan paragraf. Penyebab kesalahan dalam penelitian sebelumnya meliputi penguasaan kaidah bahasa, kurang teliti dalam menulis, pemilihan kata yang tidak tepat, penyususnan kalimat serta pembuatan paragraf.

\section{METODE}

Penelitian ini dilaksanakan di SDN Bangunrejo Kidul 1 Kecamatan Kedunggalar Kabupaten Ngawi. Subjek penelitian adalah kesalahan menulis deskripsi dan narasi dalam pelajaran bahasa Indonesia, sedangkan objek penelitian adalah siswa kelas $\mathrm{V}$ SDN I Bangunrejo Kidul 1 Kecamatan Kedunggalar Kabupaten Ngawi. Penelitian ini menggunakan pendekatan kualitatif dengan jenis penelitian deskriptif. Teknik pengumpulan data menggunakan dokumentasi, observasi, dan wawancara. Sumber data yang digunakan berupa dokumen hasil menulis deskripsi dan narasi siswa kelas $\mathrm{V}$ SDN Bangunrejo Kidul 1 secara individu, hasil observasi observasi di kelas, dan wawancara dengan guru kelas dan siswa yang menjadi objek penelitian. Teknik observasi yang digunakan adalah observasi langsung tidak berperan. Teknik ini sengaja digunakan oleh peneliti guna mendapatkan informasi yang lebih lengkap. Sedangkan teknik wawancara yang digunakan adalah wawancara mendalam (in-depth interviewing). Setelah data diperoleh peneliti menganalisis data dengan cara reduksi data, penyajian data dan menarik simpulan. Untuk menganalisis data, sampling dalam penelitian ini adalah purposive sampling. Data divalidasi dengan menggunakan triangulasi teknik.

\section{HASIL DAN PEMBAHASAN}

Dalam penelitian ini peneliti menemukan kesalahan yang dilakukan siswa kelas $\mathrm{V}$ dalam menulis. Kesalahan-kesalahan yang dilakukan siswa dalam menulis deskripsi dan narasi pada pelajaran bahasa Indonesia dapat diklasifikasikan sebagai berikut.

Tabel 1.1. Jenis kesalahan

\begin{tabular}{lll}
\hline NO & \multicolumn{1}{c}{ Jenis Kesalahan } & \multicolumn{1}{c}{ Klasifikasi Kesalahan } \\
\hline 1. $\begin{array}{l}\text { Penggunaan huruf } \\
\text { kapital }\end{array}$ & $\begin{array}{l}\text { a. Tidak pada awal kalimat } \\
\text { b. Penulisan nama orang atau nama tempat } \\
\text { c. Di tengah kata } \\
\text { d. Awal kata di tengah kalimat. }\end{array}$ \\
$\begin{array}{ll}\text { 2. Penggunaan tanda } & \text { a. Di akhir kalimat. } \\
\text { 3. Penggunaan kata di- } & \begin{array}{l}\text { a. Penulisan kata depan di- yang disambung dan kata } \\
\text { kerja pasif yang dipisah pada kalimat. }\end{array}\end{array}$ \\
\hline
\end{tabular}

\section{Kesalahan penggunaan huruf kapital}

Peneliti menemukan 55\% kesalahan siswa dalam mennggunakan huruf kapital. Ada tiga kriteria kesalahan pada kesalahan penulisan huruf kapital, yaitu kesalahan pada awal kalimat (15\%), penulisan judul (10\%), nama kota/orang (20\%), dan penulisan huruf kapital yang tidak pada tempatnya (10\%). Kesalahan-kesalahan ini dilakukankan oleh siswa kelas $\mathrm{V}$ baik pada kegiatan menulis deskripsi maupun narasi. Untuk lebih jelasnya perhatikan deskripsi di bawah ini. 
a) Sebuah gunung dan Pemandangan di sekitar yang sangat indah, sebuah gunung yang terletak di daerah Probalingga.

b) MEJA tersebut berada di atas karpet berwarna merah.

c) aku memilih menggunakan kereta dari yogya sampai banyuwangi yang membutuhkan waktu 14 jam lamanya.

Beberapa contoh kesalahan penggunaan huruf kapital dilakukan oleh siswa kelas V SDN Bangunrejo I adalah kata Pemandangan, MEJA, yogya, dan banyuwangi. Kata pemandangan dalam kalimat ini bukan suatu nama tempat atau lokasi secara geografis, namun suatu kata nomina yang berasal dari kata pandang. Pemandangan merupakan suatu suatu gambaran alam yang dapat dinikmati dengan indera penglihatan kita atau yang dapat dipandang. Dalam hal ini kata pemandangan tidak berada di awal kalimat dan bukan suatu nama tempat atau lokasi geografis, sehingga tidak ditulis dengan huruf kapital. Oleh karena itu kalimat yang benar adalah Sebuah gunung dan pemandangan di sekitar yang sangat indah, sebuah gunung yang terletak di daerah Probalingga. Penggunaan huruf kapital pada kata MEJA tidak tepat karena bukan judul atau nama singkatan, namun nama benda. Penggunaan huruf kapital pada kata meja dalam kalimat MEJA tersebut berada di atas karpet berwarna merah yang benar adalah Meja karena hanya merupakan huruf awal kalimat. Pada kalimat aku memilih menggunakan kereta dari yogya sampai banyuwangi yang membutuhkan waktu 14 jam lamanya terdapat tiga kesalahan yaitu tidak menggunakan huruf kapital pada kata aku, yogya, dan banyuwangi. Kata aku seharusnya menggunakan huruf kapital karena terletak pada awal kalimat. Begitu juga kata yogya dan banyuwangi seharusnya menggunakan huruf kapital pada awal karena nama suatu tempat atau kota. Sehingga penggunaan huruf kapital dalam kalimat tersebut adalah Aku memilih menggunakan kereta dari Yogya sampai Banyuwangi yang membutuhkan waktu 14 jam lamanya.

\section{Kesalahan tanda baca titik (.)}

Dalam penelitian ini, peneliti menemukan $15 \%$ siswa tidak menggunakan tanda baca titik (.) diakhir kalimat. Tanda baca titik (.) tidak digunakan dalam menulis deskripsi dan narasi. Kesalahan menulis tersebut peneliti temukan pada teks lembar kerja siswa menulis deskripsi dan narasi yang dikerjakan pada saat pelajaran bahasa Indonesia di dalam kelas. Di bawah ini menemukan kesalahan menulis siswa deskripsi dan narasi. Perhatikan contoh berikut.

a). Rumahku adalah rumah mungil di depan mushola

Rumah itu mempunyai luas sekitar 36 meter persegi

Dari kesalahan menulis yang dilakukan siswa dalam penggunaan tanda baca titik (.) di akhir kalimat membuat arti yang tidak jelas. Kesalahan dalam penggunaan tanda baca titik (.) merupakan kesalahan yang dilakukan oleh beberapa anak saja. Kesalahan tersebut tidak disengaja oleh mereka. Kesalahan-kesalahan yang dilakukan oleh siswa karena kurang teliti dan tergesa-gesa dalam mengerjakan menjadi tidak menuliskan tanda baca titik (.) pada tulisan deskripsi dan narasi.

Kesalahan penggunaan kata di- pada kata depan dan kata kerja.

Dalam penelitian ini, peneliti menemukan 30\% siswa melakukan kesalahan berbahasa dalam penggunaan kata di- pada menulis deskripsi dan narasi. Ada dua kesalahan penggunaan atau penempatan kata di- yang digunakan sebagai kata depan ataupun kata verba pasif. Hal ini dintengarai dengan penggunaan kata di- yang ditulis dalam kata sambung atau terpisah. Oleh sebab itu, peneliti merasa penting untuk diperbaiki kesalahan menulis siswa dalam menulis deskripsi dan narasi. Di bawah ini merupakan penemuan peneliti tentang kesalahan dalam penggunaan kata di- baik dalam menulis deskripsi seperti di bawah ini.

a) Meja tersebut berada diatas karpet berwarna merah.

b) Depan rumah penuh dengan tanaman yang di tanam 
c) Aku pun membuka mataku dengan sangat berat dan melihat kearah jam dinding yang ada dikamarku.

Kata diatas dalam kalimat Meja tersebut berada diatas karpet berwarna merah, dan di tanam dalam kalimat Depan rumah penuh dengan tanaman yang di tanam. Dalam hal ini, siswa kurang menguasai kaidah bahasa dan teliti dalam menggunakan kata depan di dengan verba pasif di-. Terdapat perbedaan penulisan atau penggunaan kata di yang sesuai dengan kaidah bahasa Indonesia. Kata di pada kata depan semestinya ditulis secara terpisah, namun sebaliknya untuk di pada verba yang bersifat pasif ditulis sambung. Sehingga kalimat Meja tersebut berada diatas karpet berwarna merah semestinya menjadi Meja tersebut berada di atas karpet berwarna merah, dan kalimat Depan rumah penuh dengan tanaman yang di tanam menjadi Depan rumah penuh dengan tanaman yang ditanam. Penggunaan kata dikamarku pada kalimat Aku pun membuka mataku dengan sangat berat dan melihat kearah jam dinding yang ada dikamarku. Kata dikamarku merupakan kata depan yang seharusnya ditulis secara terpisah bukan disambung. Sehingga kalimat tersebut penulisannya adalah Aku pun membuka mataku dengan sangat berat dan melihat kearah jam dinding yang ada di kamarku.

Hasil penelitian ini lebih mempertegas dan memperluas hasil penelitan dari Sholikah, Suyitno, dan Martutik (2013). Salah satu temuan penelitian yang dilakukan oleh Sholikah, Suyitno, dan Martutik adalah penggunaan ejaan dan tanda baca yang mencakup tanda titik, tanda koma, tanda kutip, tanda pisah, tanda hubung, tanda seru, tanda tanya, tanda titik dua, dan tanda titik koma, huruf kapital, preposisi, partikel, kata turunan, kata ganti, kata asing, angka dan lambang bilangan, singkatan, akronim. Ini menunjukkan bahwa penghilangan atau tanpa penggunaan tanda titik di akhir kalimat merupakan suatu kesalahan yang kaprah (kesalahan umum) dalam berbahasa yang dilakukan siswa baik di tingkat Sekolah Dasar sampai Sekolah Memengah Atas. Akan tetapi dalam penelitian yang dilakukan Sholikah, Suyitno, dan Martutik ini tidak mengkaji penggunaan kata di- pada kata depan atau kata verba pasif. Namun sebaliknya pada penelitian yang dilakukan oleh Ayuningsih (2012) hanya menemukan kesalahan pada penulisan huruf kapital dan kata depan di- tidak pada penggunaan tanda baca titik (.).

Temuan hasil penelitian ini berbeda dengan penelitian yang dilakukan oleh Ariningsih, Sumarwati, dan Saddhono (2012) dan Ayudia, Suryanto, dan Waluyo (2016). Salah satu temuan hasil penelitian yang dilakukan oleh dua kelompok tersebut adalah pada tataran yang lebih tinggi, yaitu kesalahan ejaan, kesalahan diksi, kesalahan kalimat dan kesalahan paragraf. Sedangkan dalam penelitian ini peneliti menemukan kesalahan pada tataran yang lebih rendah yakni pada tataran kata yang diwujudkan dalam huruf kapital, tanda baca titik (.) dan penggunaan kata depan di-. Penelitian ini menemukan bahwa kesalahan dalam penghilangan tanda titik (.) pada akhir kalimat sudah lumrah (kesalahan umum) yang dilakukan siswa dari tingkat Sekolah Dasar sampai tingkat Sekolah Menengah Atas. Hal ini harus diberi perhatian lebih dari para guru pelajaran bahasa Indonesia untuk menekankan pentingnya penggunaan tanda baca, khususnta tanda baca titik (.).

Untuk penyebab kesalahan berbahasa yang dilakukan oleh siswa dari penelitian ini dengan penelitian sebelumnya sebagian sama yakni karena kurang menguasai kaidah bahasa dan kurangnya ketelitian siswa dalam menulis. Temuan hasil penelitian Ayudia, Suryanto, dan Waluyo (2016) membuktikan bahwa kesalahan berbahasa yang dilakukan siswa disebabkan oleh siswa kurang menguasai kaidah bahasa, siswa tidak teliti dalam menulis, siswa kurang termotivasi menulis, dan siswa kurang menguasai banyak kosakata. Ini menunjukkan bahwa penyebab kesalahan berbahasa yang dilakukan siswa dalam menulis ada kesamaan, yaitu kekurangtelitian siswa dalam menulis karangan. Hal ini dapat terjadi dimungkinkan karena siswa kurang menguasai kaidah bahasa dan kurangnya latiohan yang diberikan oleh guru. Seperti temuan 
penelitian Ariningsih, Sumarwati, dan Saddhono (2012) yang menunjukkan penyebab kesalahan bahasa karena kurangnya penguasaan bahasa siswa, siswa kurang latihan menulis karangan, guru kurang memberi contoh menulis karangan, kurangnya waktu yang tersedia dalam pelajaran menulis, serta adanya pengaruh bahasa asing.

\section{SIMPULAN}

Peneliti menyimpulkan bahwa kesalahan siswa kelas V SDN Bangunrejo I dalam menulis deskripsi dan narasi ada pada penulisan huruf kapital, tanda baca titik (.) dan penggunaan kata di-. Kesalahan ini disebabkan oleh sikap siswa yang kurang teliti dalam mengerjakan. Siswa selalu tergesa-gesa dan kurang teliti dalam menyelesaikan tugas. Rasa ingin cepat selesai dan segera mengumpulkan yang membuat siswa tidak fokus dalam menulis deskripsi dan narasi. Siswa juga jarang sekali mau memeriksa kembali hasil menulis dengan tujuan supaya dapat mengoreksi kesalahan. Guru sudah berupaya supaya siswa mampu menyelesaikan menulis deskripsi dan narasi dengan benar. Namun pada kenyataannya siswa masih selalu melakukan kesalahan dalam menulis. Untuk mengurangi tingkat kesalahan menulis siswa kelas $\mathrm{V}$ dalam deskripsi dan narasi yaitu: pertama, peran guru sangatlah penting dalam pembelajaran di dalam kelas. Guru harus dapat membuat nyaman dan aktif pada setiap siswa. Rasa nyaman dan senang sangat mempengaruhi penerimaan siswa pada saat pembelajaran sehingga siswa ingin selalu belajar di dalam kelas. Kedua, meningkatkan kegiatan menulis siswa dalam pembelajaran sehingga siswa sudah terbiasa dengan kegiatan menulis deskripsi dan narasi. Dengan seringnya menulis diharapkan siswa mampu mengurangi kesalahan dalam menulis deskripsi dan narasi.

\section{DAFTAR PUSTAKA}

Ananda, Rizki., Sofyan A Gani, dan Gani Rosnani Sahardi. (2014). "A Study of Error Analysis from Students' Sentences in Writing". Studies in English Language and Education. Vol. 1, No. 2, hal. 81-95. P-ISSN 2355-2794, E-ISSN 24610275.

Ariningsih, N.E., Sumarwati, dan Kundharu Saddhono (2012). "Analisis Kesalahan Berbahasa Indonesia dalam karangan Eksposisi Siswa Sekolah Menengah Atas". BASASTRA: Jurnal Penelitian Bahasa, Sastra Indonesia dan Pengajarannya. Volume 1 Nomor 1, Desember 2012, hal. 40-53, ISSN I23026405.

Ayudia, Edi Suryanto, dan Budhi Waluyo. (2016). "Analisis Kesalahan Penggunaan Bahasa Indonesia dalam Laporan Observasi Pada Siswa SMP". BASASTRA: Jurnal Penelitian Bahasa, Sastra Indonesia dan Pengajarannya. Volume 4 Nomor 1, April 2016. ISSN 12302-6405.

Ayuningsih. F.D. (2012). "Analisis Kesalahan Berbahasa dalam Penulisan Pengalaman Pribadi Siswa Kelas X A SMK Batik 2 Surakarta". Skripsi. Universitas Muhammadiyah Surakarta. Diakses dari http://eprints.ums.ac.id/22592/19/ NASKAH_PUBLIKASI.pdf

Dalman, H. (2014). Keterampilan Menulis. Jakarta: PT Raja Grafindo Persada.

Karim, Abdul., dkk. (2018). "Error Analysis in EFL Classroom". International Journal of English Linguistics. Vol. 8., No. 4., hal. 122-138, ISSN: 1926-869X, E-ISSN: 1923-8703.

Markhamah, \& Sabardila, A. (2010). Analisis Kesalahan dan Karakteristik Bentuk Pasif. Surakarta: Jagat ABJAD

Setyawati, N. (2010). Analisis Kesalahan Berbahasa Indonesia. Surakarta: Yuma Pustaka.

Sholikah, E. N., I. Suyitno., dan Martutik. (2013). "Analisis Kesalahan Berbahasa Dalam Karangan Tentang Perjalanan Siswa Kelas III MTsN Model Trenggalek". Skripsi. Universitas Negeri Malang. Diakses dari http://jurnal- 
online.um.ac.id/data/

artikel/

$$
\text { artikel40035D25DA09DFDF66C869B4E482145E.pdf }
$$

Slamet, St. Y. (2009). Dasar - Dasar Keterampilan Berbahasa Indonesia. Surakarta: UNS Press.

Suparno. (2011). Keterampilan Dasar Menulis. Jakarta: Universitas Terbuka.

Zen, A. M. F. (2009). "Peningkatan Keterampilan Menulis Karangan Narasi dengan Menggunakan Media Gambar Seri Pada Siswa Kelas III SD. Petarukan Pemalang 2008/2009". Skripsi. Universitas Negeri Semarang. Diakses dari https://lib.unnes.ac.id/398/. 